\title{
Assessing the impact of design on the development of digital services
}

\section{Avaliando o impacto do design no estabelecimento de serviços digitais}

\author{
Gabriel Santos Garbulho ${ }^{1}$ 이 , André Leme Fleury ${ }^{1}$, Eduardo Camillo Kasparevicis Ferreira² \\ ${ }^{1}$ Universidade de São Paulo, Escola Politécnica, Departamento de Engenharia de Produção, São Paulo, SP, Brasil. \\ E-mails: gabriel@garbulho.com.br; afleury@usp.br \\ 2Universidade de São Paulo, Faculdade de Arquitetura e Urbanismo, Departamento de História, São Paulo, SP, \\ Brasil. E-mail: eduardo.ckf@gmail.com
}

How to cite: Garbulho G. S., Fleury, A. L., \& Ferreira, E. C. K. (2020). Assessing the impact of design on the development of digital services. Gestão \& Produção, 27(4), e4135. https://doi.org/10.1590/0104$530 \times 4135-20$

\begin{abstract}
This paper analyzes how design diffusion is changing the organizational logics of established companies. If previously design activities had as its main objective packaging new technologies to create differentials for products and services and to reduce production costs, with the diffusion of digital services currently design activities expand its scope and identify functional and emotional needs from users that are relevant for creating differentiated experiences, that in turn will result in new products and services that incorporate existing and emerging technologies of the firm. This transformation reveals a new organizational strategy, in which design assumes a more relevant position for the creation of innovative business models. However, a point not yet considered in the literature is how companies are restructuring their operations in order to benefit from this transition. This paper analyzes how Brazilian organizations of different sizes and sectors have redefined their management models in order to incorporate design as a catalyst of change. The obtained framework consolidates the main propositions of design while directing of the changes in the organizations in the operational, tactical and strategic levels.
\end{abstract}

Keywords: Design strategy; Design management; Organizational changes; Design thinking; User experience; Agile project management.

Resumo: Este artigo discute como o design vem alterando a lógica organizacional das empresas. Se anteriormente o design tinha como objetivo principal "empacotar" tecnologias de forma a estabelecer diferenciais em produtos e serviços e reduzir seu custo de produção, atualmente, com a popularização dos serviços digitais, o design expande seu escopo e passa a identificar necessidades funcionais e emocionais dos usuários, capazes de resultar em experiências de uso diferenciadas, que serão materializadas em produtos e serviços que incorporam as tecnologias da organização. Esta transformação evidencia uma nova estratégia organizacional, na qual o design assume posição de maior relevância no estabelecimento de modelos de negócios inovadores, viabilizados a partir da criação de novas experiências para os usuários. Porém, um ponto ainda não desenvolvido na literatura diz respeito a como as empresas vem se reestruturando de forma a enfrentar e se beneficiar com essa transição. Este artigo analisa como organizações brasileiras, de diferentes portes e segmentos, redefiniram seus modelos de gestão de forma a incorporar o design enquanto catalizador dessa mudança. $O$ referencial obtido

Recebido Mar. 15, 2018 - Aceito em Abr. 20, 2019

Financial support: None.

This is an Open Access article distributed under the terms of the Creative Commons Attribution License, which permits unrestricted use, distribution, and reproduction in any medium, provided the original work is properly cited. 
consolida as proposições principais do design enquanto direcionar das mudanças nas organizações nos níveis operacional, tático e estratégico.

Palavras-chave: Estratégia de design; Gestão do design; Mudança organizacional; Design thinking; Experiência do usuário; Gestão ágil de projeto.

\section{Introduction}

Design is a strategic problem-solving process that drives innovation, builds business success, and leads to a better quality of life through the development of innovative products, services, systems and experiences (WDO, 2018). By the end of the first decade of the twenty-first century the demand for digital services began to consolidate with the use of the mobile channel, which became a definitive relationship tool, making possible for companies to develop a pervasive electronic presence with their consumers, all the time, in any place (Varnali \& Toker, 2010). This new context of use, involving intermittent electronic availability and the virtual presence of services, reinforced the personal relationship between customer and companies, which now involves different levels of connections (rational, emotional, physical and sensorial). This new set of service attributes is defined as customer experience (Gentile et al., 2007).

According to Hassenzahl (2010), "an experience is a story, emerging from the dialogue of a person with her or his world through action", and all experiences have an emotional route (Hassenzahl et al., 2013). In this context Krippendorf (2006) defines product semantics as the systematic investigation of how people attribute meanings to and artificially interact with products, and reinforces that product semantics is the key to enhance the experience perceived by the users. Design research aims to create and to improve tools for investigating the meanings of experiences, including user-centered design, an approach that focuses on end-user needs to guide the development of new services, products and systems (Lai \& Yang, 2009; Norman, 2013), helping in the determination of the scope of technological projects considering the miniaturization and digitization of available technologies for the use of non-specialists (Krippendorf, 2006).

The success of a company is based on its ability to develop new competences to create and to sustain competitive advantages (Prahalad \& Hamel, 1990). Design is considered core for digital companies because of its potential to access new markets and to maximize the perceived benefits by end customers in a unique way (Mozota, 2011). Some organizations already recognize that their internal processes should be intimately connected with the holistic experience provided for the customer and, therefore, are changing the focus of process improvement, from an operational perspective to a perspective based on the requirements of the people that they serve (Junginger, 2008).

In this context, design management, defined by Gorb (1995) as the effective distribution by managers of the design resources available at the company to contribute for the achievement of its objectives, expands its possibilities, not only in the sense of generating value for the user, but also in supporting the review of the organizational logic of a company. Design strategy is a plan that helps to spread the design activities through the corporation, reinforcing its of relationships with management considering operational, tactical and strategic scopes (Mozota, 2011).

However, a topic not yet developed in the literature concerns how companies have been restructuring their processes in order to benefit from the adoption of design as a catalyst process of organizational change, which has the user as the starting point for 
the design of experiences that are made possible through the products and services that incorporate the technologies of the organization.

This paper analyzes how Brazilian companies, of different sizes and segments, have redefined their management models in order to incorporate design as a catalyst for these changes. The main objective of the study is to investigate the design practices in the operational, tactical and strategic dimensions of digital service companies, aiming to identify the organizational changes generated with the incorporation of a design management model, aiming to contribute with the evolution of the theoretical basis that supports the practices in the area.

The relevance of the theme is justified because of the lack of research with focus on understanding the influence caused by design on organizational changes and on user experiences (Buchanan, 2008) considering the current equivalence of the importance of design strategy in relation to business plans (Katz, 2015). This study is aligned with research that considers that the focus on the customer is the main route for the establishment of competitive advantages (Gentile et al., 2007) and, therefore, considers that strengthening the relations between design activities and business processes can be decisive for achieving this differential.

The paper is structured as follows: the first section contextualizes the research, presents its objectives and justifies its relevance; the second section presents the main concepts related to design at the operational, tactical and strategic levels; the third section presents the research method; the results obtained with the conducted initiatives are presented in the fourth section; finally, the fifth section presents the main conclusions obtained with the research.

\section{Literature review}

The bibliographic topics of interest for this research include the different perspectives of design involvement for the management of the companies proposed by Mozota (2011), including operational management of the design, tactical management of design and the strategic management of the design. According to Krippendorf (2006), design management includes a set of organizational skills to encourage innovation and technological development. Cross (2001) describes design as a distinct discipline, based on the rigor of its particular thinking, different from science, but combining values from arts and from sciences. The model of decision making applied by designers was recognized as a proper and characteristic way of thinking and organizing ideas from scientific and artistic processes, and whose methods of modeling, pattern generation and synthesis are related to a reflexive practice and to the use of an intuitive process to deal with uncertainty (Cross, 2001).

In this context, design is a process that recognizes and promotes a unique system of competencies, capable of meeting the explicit and latent needs of users, dealing with different limitations, challenging the natural attitudes of an organization regarding the preservation and resistance to changes, and evidencing two main contributions: one related to the resolution of specific problems and the other related to the discovery and use of new opportunities identified in the organization's operating environment (Junginger, 2008; Boland, 2004; Deserti \& Rizzo, 2014; Zurlo \& Cautela, 2014) . 


\subsection{Operational management of design}

In the operational level design activities aim to generate value aligned with primary functions of marketing and production. This definition places design within the traditional limits of the designer's performance and is related to its industrial origins (Mozota, 2011). The knowledge of design considered in the operational level is associated with a specific know-how, in which the designer's capabilities are realized in the activities with materials, with artifacts, with the conditions in which they are made, and in the way they will be produced. However, these are usually executed in conditions of complexity, because designers deal with different variables that interact in unpredictable ways (Schön, 1988).

When designing and developing digital interfaces, designers tackle problems that are distinct from the problems traditionally encountered by scientists and engineers, which are usually defined, divisible, with finite possibilities of solutions, and with at least one correct solution (Simon, 1973). The problems faced by designers are poorly formulated, described by imperfect and eventually contradictory information, generated by users, clients and decision makers who present conflicting values and interests, leading to solutions whose answers do not appear to be right or wrong, but rather better or worse considering the different implementation contexts. These problems are known as wicked problems and generate processes of perception, cognition and notation that are used by the designer to think and to create their lines of action (Simon, 1969; Rittel, Webber, 1973; Buchanan, 1992; Schön, 1988).

In the end of the 20th century, the advance of highly complex technologies with a common focus on users, mainly in the Silicon Valley, resulted in a new context with particularities in which designers are responsible for planning and mediating the complexity of technological devices and their users, in the "human-machine" interfaces (Katz, 2015). The main aspects of this interface are interactivity, dynamics and autonomy, which directly influence usability, defined more broadly as the set of aspects of human-computer interaction dedicated to ensuring that the interaction will be, among other things, effective, efficient and satisfactory for the user (Krippendorf, 2006; Hartson \& Pyla, 2012).

At the operational level, designers suggest directions and propose ways for the areas involved in the project to understand and to explore possibilities in order to make their contributions feasible and to attract sufficient resources to make the project happen. (Krippendorf, 2006). The demands for designers considered in this scenario involve the solving of problems considering business and technology strategies (Mozota, 2011).

\subsection{Tactical management of design}

Research concerning user experience (UX) gained relevance and importance with the recent technological diffusion, in which UX is defined as a "complex and socially situated phenomenon in which technology acts as a mediator between the user and the activity" (Lallemand et al., 2015). Pucillo \& Cascini (2014) consider that each experience is unique in the particular context of each user and, at the same time, has relative similarity with the common interest of groups of users.

The shift of focus from the technological and instrumental criteria to more general factors of user experience aiming to generate UX theoretical basis forced researchers to consider new metrics and specialized models (Law et al., 2014). A systematic 
evaluation of UX publications from 2005 to 2009 developed by Bargas-Avila \& Hornbæk (2011) evidenced that most of UX research is qualitative, mainly with the use of traditional usability artifacts, such as questionnaires and scales. Along with other attributes, emotion, use, and aesthetics are the most frequently measured dimensions and the context of use began to incorporate, in addition to work situations, leisure activities made possible by consumer products (Law et al., 2014). Most methods focus on momentary evaluations, based on task-oriented assessments (Kujala et al., 2011). Innovative research approaches are still minority, although there are experiments that consider physiological responses (heart rate, contraction of the skin) and narrative analysis (Law et al., 2014).

Considering the levels of perception categorized by Norman (2004), Thüring \& Mahlke (2007) developed a model, presented in Figure 1, which synthesizes the combination of the perception of qualities called non-instrumental qualities (subjective qualities related to aesthetics and pleasure) with the instrumental qualities (related to the effectiveness of use), which together with the emotions provoked make up the user experience, which determines the appreciation of a system.

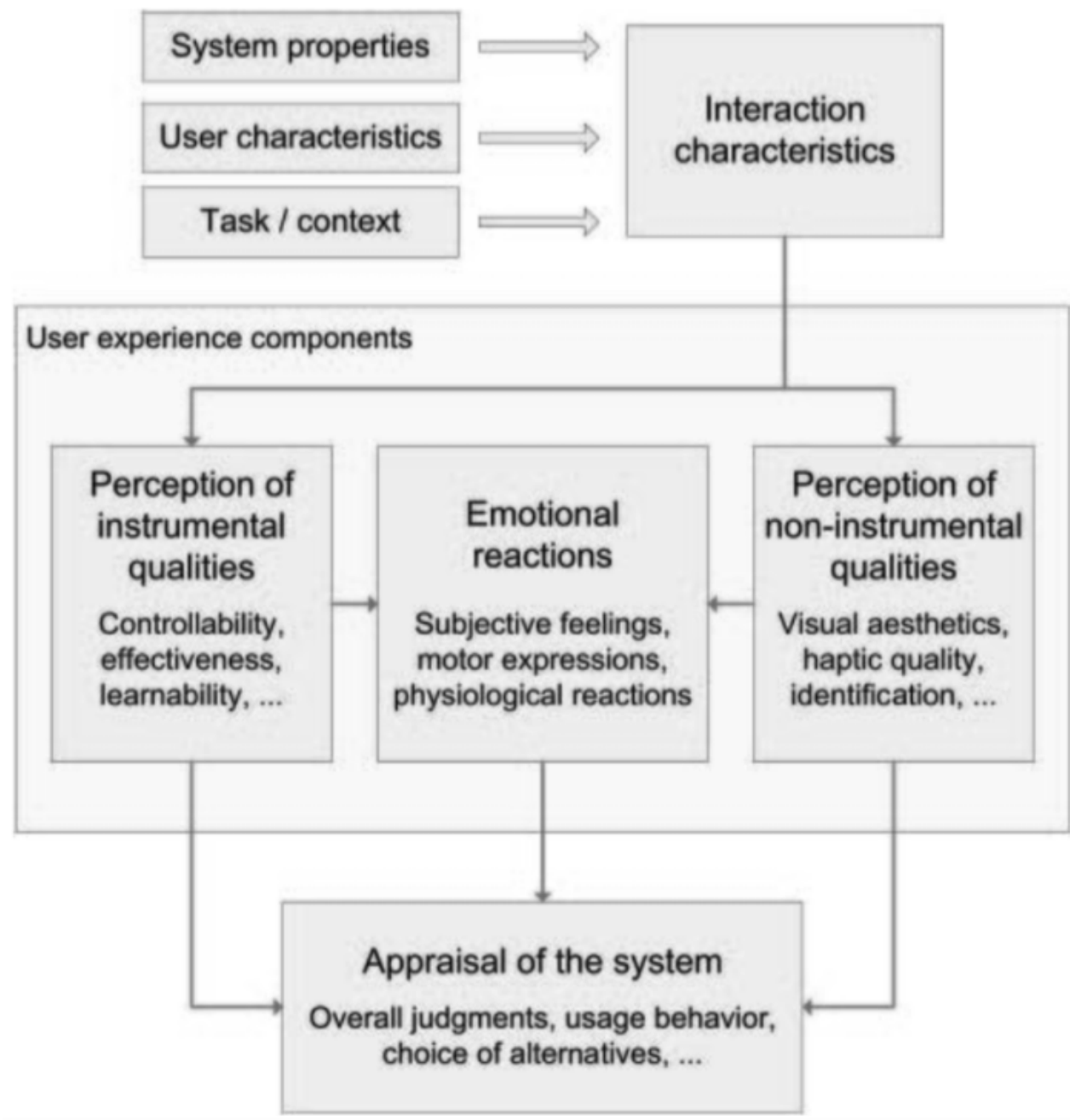

Figure 1. CUE Model Source: adapted from Thüring \& Mahlke (2007). 
Therefore, tactical management of design promotes and enhances the connections between sociocultural models represented by consumer groups and productive models developed by the company; it also represents the moment when design becomes a corporate function, encompassing a set of organizational skills to encourage innovation and technological development (Krippendorf, 2006; Mozota, 2011; Zurlo \& Cautela, 2014). Among the main advantages obtained from this integration, Mozota (2011) highlights the coherence and standardization of design decisions regarding projects and the understanding of design diversity, which strengthens their space in the organizational structure.

Dickson et al. (1995) suggest five main skills that characterize design inside an organization: basic skills, specialized skills, stakeholder involvement, organizational change, and innovation skills. These five skills demonstrate the expansion of the design presence in recent decades, which has become a thinking approach focused on generating changes in the different economic, social and environmental systems that surround the company (Zurlo \& Cautela, 2014). Boland (2004) considers that design makes possible a new approach for decision making and for solving managerial problems, justifying that, in this way, it avoids the premature ending of the process of understanding and analyzing the problem and the identification and characterization of the variables that constitutes user experience.

In addition to the user experience, the consolidation of the designer's way of thinking was synthesized in a mental model that simulates design practices and popularized as Design Thinking (DT), defined by Fleury et al. (2016) as a human-centered approach, applied to solve wicked problems, beginning with the understanding of the different perspectives of users and involving multidisciplinary teams, acting in cooperation and mediating conflicts in the search for innovative solutions. Brown (2008) defines Design Thinking as a discipline that uses methods and sensitivity of designers to find solutions capable of satisfying users' needs in a technologically feasible and economically profitable way for the corporation. Abductive thinking, a mode of structured reasoning for the inference of the best response for ill-defined problems, forms the basis of design thinking and defines the balance between rationality and intuition (Brown, 2008; Martin, 2010).

Therefore, the consolidation of the Design Thinking approach incorporates the practices of designers in the search of solutions for complex problems. Buchanan (1992) foresaw the evolution of Design Thinking for the systematic generation of solutions related to communication, construction, strategic planning, and systemic integration. This growth in recognition and importance of design capabilities considering business contexts can be seen as the natural evolution of design, and its expertise must be spread throughout the organization, implying a change in processes, performance measurement, human resources policies, and models of management, and acting as a facilitator of organizational change driven by consumer vision (Brown \& Katz, 2011; Galbraith, 2002).

For a better exploitation of these emerging opportunities, Martin (2010) considers appropriate to adopt project-oriented structures inside the organization, since these are not attributed to individuals, but to teams, and therefore, it is expected that the solution is obtained in a collaborative way. In the search for a dynamic balance between differentiation and integration, the distribution of people in project teams has been a solution often adopted by companies in the search of continuous innovation. In this context, agile project management combined with user-centered design provides a balance between delivery time and involvement of different stakeholders in all stages of the project, avoiding communication problems (Mafakheri et al., 2008; Chamberlain et al., 2006; Moreira \& Queiroz, 2007). 
The project view is an artifact that defines the soul of the project and links its participants around the main objectives that the project aims to achieve, so that everyone can identify (Christensen, 1997). Amaral et al. (2011) argues that this vision must be understandable, motivating, credible, challenging and demanding. With these balanced factors, the vision allows sharing the understanding of the product or service for all team members, and strengthens the unification of the language for project communication within that context. In general, agile methods emphasize performance management, people's participation, and especially the user context, encouraging their participation during the development process, which is structured into short-lived continuous cycles with smaller deliveries for rapid evaluation and learning (Chamberlain et al., 2006; Sheffield \& Lemétayer, 2013).

\subsection{Strategic management of design}

Understanding the forces that shape competition is the starting point for developing the strategy and seeking more favorable positions for the company. Porter (2008a) identifies five main forces that shape strategy, and the forces that have greatest impact on the profitability of the business should be considered as major competitive forces: threat of new entrants, bargaining power of suppliers, threat of substitute products, bargaining power of customers and rivalry between competitors. Still according to Porter (2008b), the essence of strategy lies in choosing what not to do. While the goals indicate what a business unit wants to achieve; the strategy describes the plan to achieve these goals (Kotler, 2002).

Considering the strategies proposed by Porter (2008a), Mozota (2011) presents three possible strategic lines of action for design as a enabler and potentializer of organizational strategy: a market-oriented strategy, in which design positions the company as a specialist in a particular segment of users; an image-oriented strategy, in which the performance of design aims to reinforce the company's participation in a given market and strengthen its brands; and the cost-oriented strategy, in which design works with a focus on improving the different aspects that affect the organization's productivity. The success of strategy and design strategy depends on doing things well and integrating them (Mozota, 2011).

Strategic design management concerns the development of the relationship among design, strategy, identity and culture of a company, inserting design into strategy creation and, as a consequence, determining the design strategy (Mozota, 2011). Thus, design at the strategic level structures a systematic approach for understanding the dynamics and effects of material and immaterial relationships, which are articulated through collective processes with the aim of sharing meanings and languages, influencing and modifying sociocultural models of the organization (Verganti, 2008; Deserti \& Rizzo, 2014)

The positioning of design in a particular company allows the visualization of disruptive meanings and languages that may emerge in the future, and which can only be well utilized if the design strategy is situated in the same context of the company's strategy (Verganti, 2008; Deserti \& Rizzo, 2014). In this way, while user-centered design has the merit of valuing the concept of a product before its development, designdriven innovation focuses on an even more primary stage in which companies understand the dynamics of sociocultural models and think about new languages and product views in an exploratory way (Verganti, 2008). 


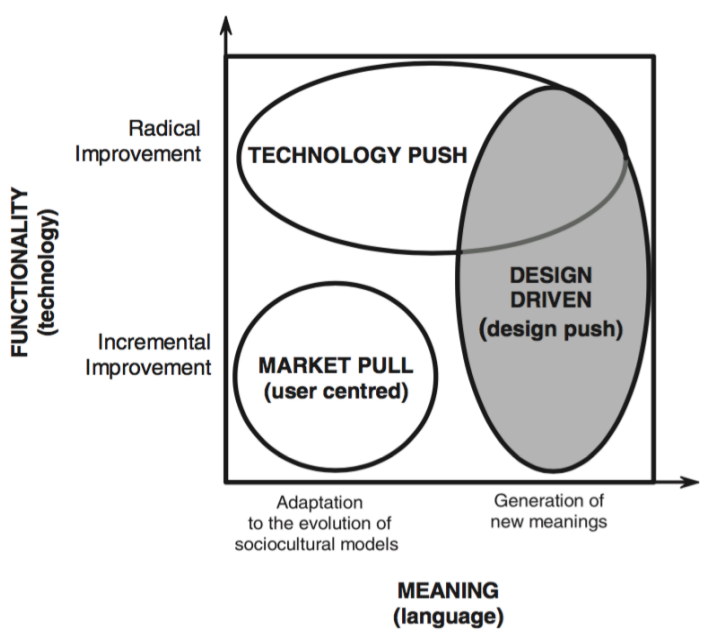

Figure 2. Functionality (technology) X Meaning (language). Fonte: Verganti (2008), p.444.

Design-driven innovation, as seen in Figure 2, is not a response to user needs, but rather a proposal for market modification, exploring trends with a higher chance of future diffusion inside society, and may be associated with technological disruptions, since they often cause or are caused by radical changes in the meaning of products (Verganti, 2008).

Thus design-driven innovation is enhanced by the successful implementation of a technology strategy, based on a daily technology management routine, capable of ensuring critical decisions and changes in a timely and satisfactory manner, directly impacting business (Gregory, 1995). As a result of extensive studies, Christensen (1997) asserts that the essence of technological strategy lies in identifying the inflection point of the "S" curve of diffusion of a particular technology, in order to identify and develop the next successor of incoming technologies and that will effectively supplant the current technology.

Zurlo \& Cautela (2014) propose the use of strategy as a narrative to facilitate the interpretation of the process of creating meaning for organizations. Considering as drivers the two most importat aspects of the strategic narrative (market and technology), the authors propose the division presented in Figure 3, which characterizes the narrative type of the design strategy according to these premises (Zurlo \& Cautela, 2014).

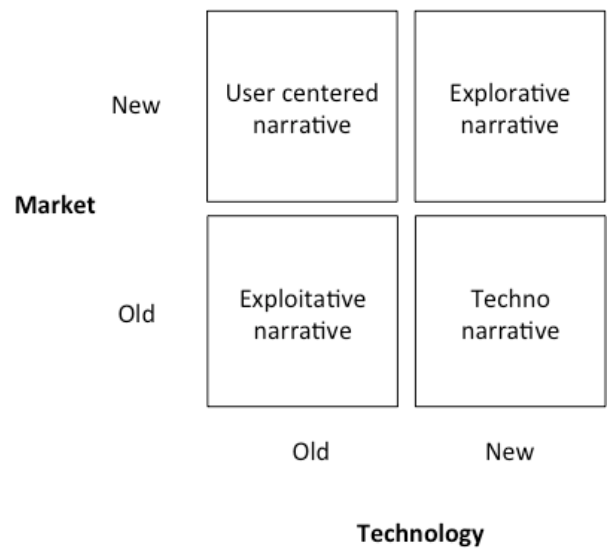

Figure 3. Market X Technology Fonte: Zurlo \& Cautela (2014), p.24. 
In this model four key narratives are identified considering the relationship between technology and market innovation: the exploitative narrative, in which design is oriented to solve problems with well-defined opportunities and constraints, without space for expansion of the business model; the technological narrative, in which the designer is required to use and to introduce a new technology to develop a new product or service; the user-centered narrative, in which the company demands from the designer the proposition of a new scenario and context for the expansion of the use of a existing technology, explored from the vision of new users within the intended audience; and the explorative narrative, which has a greater potential for innovation than the previous ones, because in this scenario designers are required to imagine solutions that can modify or create business models considering technological capabilities (Zurlo \& Cautela, 2014).

The real innovation driver that can change companies, their processes and competencies is in the management of innovative projects using a design culture based on the company narrative, and the change of focus from the product to the user demands the development of new products to explore opportunities of innovation in the context of their own research, influencing the organization's strategy (Junginger, 2008; Deserti \& Rizzo, 2014).

\subsection{Main contributions and research themes}

The most important theories, concepts and propositions related with design at the operational, tactical, and strategic levels previously presented have been organized in themes aiming to generate the questions that will be explored during the conduction of the case studies of this research. Table 1 syntethises the main contributions identified and the concepts directly related with each contribution.

Table 1. Themes, authors and theoretical propositions.

\begin{tabular}{|c|c|}
\hline Themes and main authors & Proposed topics for the case studies \\
\hline $\begin{array}{l}\text { Problem characterization } \\
\text { (Simon, 1969; Simon, 1973; } \\
\text { Rittel \& Webber, 1973) }\end{array}$ & $\begin{array}{l}\text { 1. Design contributes for the dynamic definition of the } \\
\text { tackled wicked problems and creates business } \\
\text { opportunities from changes of scope. }\end{array}$ \\
\hline $\begin{array}{l}\text { Design and User Experience } \\
\text { (UX) (Lallemand et al., 2015) }\end{array}$ & $\begin{array}{l}\text { 2. Designers master techniques for understanding } \\
\text { contexts of use and handling the semantycs of products } \\
\text { and services considering users' point of view and } \\
\text { therefore designers are the most capable professionals } \\
\text { for mediating User Experience (UX) criteria. }\end{array}$ \\
\hline $\begin{array}{l}\text { Usability emotional criteria } \\
\text { (Law et al., 2014) }\end{array}$ & $\begin{array}{l}\text { 3. Emotional dimensions are deteminant for the success } \\
\text { considering the relationship between customers and } \\
\text { organizations, however there is still a lack of indicators } \\
\text { for measuring this impact on business performance. }\end{array}$ \\
\hline UX Metrics (Law et al., 2014) & $\begin{array}{l}\text { 4. A view with focus on user experience aims to evaluate } \\
\text { how positive has been the significance of the products } \\
\text { and services for the users. }\end{array}$ \\
\hline $\begin{array}{l}\text { Design management } \\
\text { fundamentals (Dickson et al., } \\
\text { 1995) }\end{array}$ & $\begin{array}{l}\text { 5. Design management is independent from other } \\
\text { organizational functions and analyses its capability in } \\
\text { influencing the promotion of innovations and } \\
\text { organizational change. }\end{array}$ \\
\hline $\begin{array}{l}\text { Design Thinking (Brown, 2008; } \\
\text { Martin, 2010; Dorst, 2011; } \\
\text { Hartson \& Pyla, 2012) }\end{array}$ & $\begin{array}{l}\text { 6. Design Thinking applies design approaches aiming to } \\
\text { identify the best solutions for complex problems in } \\
\text { different áreas. }\end{array}$ \\
\hline
\end{tabular}


Table 1. Continued..

\begin{tabular}{|c|c|}
\hline Themes and main authors & Proposed topics for the case studies \\
\hline $\begin{array}{l}\text { Agile Project Mangament } \\
\text { (Chamberlain; Sharp \& Maiden, } \\
\text { 2006; Martin, 2010; } \\
\text { Amaral et al., 2011; Sheffield \& } \\
\text { Lemétayer, 2013) }\end{array}$ & $\begin{array}{l}\text { 7. Agile Project Management is ideal for promoting the } \\
\text { involvement of all areas in the different project phases, } \\
\text { sharing the alignment of objectives and the project view, } \\
\text { looking for better opportunities with the proposition of } \\
\text { value considering the user point of view. }\end{array}$ \\
\hline $\begin{array}{l}\text { Design driven innovation } \\
\text { strategy (Junginger, 2008; } \\
\text { Verganti; 2008; Zurlo; Cautela, } \\
\text { 2014; Deserti \& Rizzo, 2014) }\end{array}$ & $\begin{array}{l}\text { 8. Design is the catalyst of innovation opportunities that } \\
\text { emerge during development and that can be interpreted } \\
\text { in alignment with a sociocultural context (user centered), } \\
\text { or as a market change proposal (design driven), that can } \\
\text { be associated with a new technology. }\end{array}$ \\
\hline $\begin{array}{l}\text { General strategy concepts } \\
\text { (Kotler, 2002; Porter, 2008a; } \\
\text { Mozota, 2011) }\end{array}$ & $\begin{array}{l}\text { 9. Association of design with the generic strategies of an } \\
\text { organization potentialize competitive advantages }\end{array}$ \\
\hline $\begin{array}{l}\text { Technology strategy (Gregory, } \\
\text { 1995; Christensen, 1997) }\end{array}$ & $\begin{array}{l}\text { 10. Technology strategies contribute to identify the best } \\
\text { moments for investing in disruptive innovations aiming to } \\
\text { follow the technological evolution that changes the } \\
\text { approach for a specific market. }\end{array}$ \\
\hline
\end{tabular}

Source: Created by the authos.

\section{Method}

This research conducted an exploratory case study, focusing on the understanding of the dynamics present in unique configurations, with the purpose of generating propositions capable of sustaining future explorations about the design process inside organizations (Eisenhardt, 1989). Case studies allow the understanding of the real world in contexts in which the researcher has little possibility of manipulating their characteristics (Mccutcheon \& Meredith, 1993), make possible the establishment of generic models (Martikainen et al., 2013) and allow better understanding of the present in the real context, being appropriate for the understanding and reality of the design in the different levels of analysis proposed in this research: operational, tactical and strategic.

A case study considers preliminary theoretical propositions, capable of sustaining the formulation of hypotheses and questions that will be explored in the field (Yin, 2015). Therefore, the research was divided into two main phases and they comprised: 1) the bibliographical review and the consolidation of the hypotheses and questions; and 2) the preparation, collection and analysis of cases of interest for the exploration and alignment between theory and practice.

We opted for a study including multiple cases, whose triangulation of data strengthens the potential of the results obtained from analytical generalization (Yin, 2015). For this purpose, we selected companies that conceive, develop and operate digital services and that have the internal design process in their own structure, as shown in Table 2.

Table 2. Characterization of the analyzed companies.

\begin{tabular}{ccccc}
\hline Organization & Market Segment & $\begin{array}{c}\text { Number of } \\
\text { employees }\end{array}$ & $\begin{array}{c}\text { Digital products } \\
\text { and services } \\
\text { platform }\end{array}$ & $\begin{array}{c}\text { Design } \\
\text { managemnet } \\
\text { area }\end{array}$ \\
\hline A & Financial & +100.000 & $\begin{array}{c}\text { Web and Mobile } \\
\text { (app) }\end{array}$ & $\begin{array}{c}\text { Marketing (visual } \\
\text { design) and } \\
\text { Business (UX) }\end{array}$ \\
\hline
\end{tabular}


Table 2. Continued...

\begin{tabular}{ccccc} 
Organization & Market Segment & $\begin{array}{c}\text { Number of } \\
\text { employees }\end{array}$ & $\begin{array}{c}\text { Digital products } \\
\text { and services } \\
\text { platform }\end{array}$ & $\begin{array}{c}\text { Design } \\
\text { managemnet } \\
\text { area }\end{array}$ \\
\hline B & Brewery & +30.000 & Web & Business \\
\hline C & $\begin{array}{c}\text { Logistics } \\
\text { management }\end{array}$ & $\begin{array}{c}\text { Less than } \\
500\end{array}$ & $\begin{array}{c}\text { Mobile (app) } \\
\text { web }\end{array}$ & Products \\
\hline D & $\begin{array}{c}\text { Corporate } \\
\text { education }\end{array}$ & $\begin{array}{c}\text { Less than } 10 \\
\text { pessoas }\end{array}$ & Mobile (app) & Product \\
\hline E & $\begin{array}{c}\text { App development } \\
\text { and maintainence }\end{array}$ & $\begin{array}{c}\text { Less than } \\
100 \text { pessoas }\end{array}$ & Mobile (app) & General manager \\
\hline
\end{tabular}

Source: created by the authors.

The unit of analysis investigated in this study included the activities of creation, development and operationalization of digital services, conducted by professionals and design managers. The choice of this unit aims to relate this study to the body of knowledge of design management, analyzing its evolution in a contemporary context. Due to the limitations of providing confidential information with strategic value, semistructured interviews were conducted, with a script built from the concepts and issues consolidated in the bibliographic review and presented in Table 1. Five professionals from different backgrounds were interviewed in the companies, all related to the areas of design or user experience, as shown in Table 3. The interviews were carried out in the companies under analysis, allowing the contextualisation of the main responses obtained from the interviewees. The interview audios were recorded for later analysis and tabulation.

Table 3. Organition and interviewee functional area.

\begin{tabular}{ccc}
\hline Organization & Interviewee & Area \\
\hline A & User Experience specialist & User Experience (UX) \\
\hline B & UX Leader & Products (innovation cell) \\
\hline C & UX Designer & Products \\
\hline D & Product manager & General management \\
E & UX/UI Designer & General management \\
\hline
\end{tabular}

Source: Created by the authors.

In addition to the interviews, the digital services developed by the interviewees' companies were tested and analyzed by the researchers in order to verify their consistency with the obtained answers. We also collected information available in the press and in the institutional areas of the companies, including their websites, in order to be able to ascertain results and balance sheets disclosed and the position declared by these companies in relation to the proposed subject.

\section{Results}

The interviews and other investigative procedures conducted by the researchers considering the companies of interest brought evidence for the analysis of the cases from the compilation of the information obtained in the field, considering the combination of standards, and which were generalized analytically in order to establish 
the research conclusions. Results obtained with the field research were analyzed in comparison to the relevant theoretical concepts concerning the theme and resulted in the development of four main propositions aligned with the main theoretical constructs.

\subsection{Main propositions identified}

Although differences of emphasis have been observed considering the criteria of relevance for the user experience, all the analyzed companies rely on UX professionals or design professionals to perform this task, influencing the design of the products and their improvements, incorporating outcomes from evaluations performed in the context of use, with the objective of delivering value to the end user. This reinforces the theoretical point that UX professional presents itself as the most qualified to perform the semantic mediation of the products in the context of comprehensiveness of these cases.

Research and testing tactics conducted by designers to deal with the development of user experiences in the analyzed companies are generally subordinated to the commercial performance of the company, giving the UX area the task of proving that this delivery of value to the user brings better results for the organization. This evidences the integration of the design work with the general strategy of the companies in benefit of the quality, allowing the questioning of scopes and internal determinations based on the search for better services.

Concerning satisfaction of use, the conducted research evidenced concrete aspects about the influence of the instrumental criteria in relation to the results of the services, which reinforces the greater impact of these on the performance of use. However, companies' emphasis and enthusiasm with the expansion of field research and user interviews for understanding and ideating new products indicate that the user experience is a delivery of value that is not restricted only to the context of the interface and its cognitive process, but throughout the service provision and its space of use.

Therefore, the first proposition resulitng from the empirical findings identifies that the user experience, in the context of the analyzed organizations, includes the delivery of value and meaning to the user and it is the result of his relationship with the service contact points, involving instrumental criteria as determinants of use performance, and emotional criteria as determinants of commercial success, reinforcing and complementing the concepts proposed by Law et al. (2014) and Lallemand et al. (2015).

Beyond the improvement of the strategic alignment considering the users' point of view, as presented in theory, the dissemination of tools associated with Design Thinking to organize discussions and to the co-creation processes observed at the analyzed companies evidenced that Design Thinking is becoming a common language for the treatment of requirements among project teams, ensuring not only the user's point of view but also the reliability for dealing with complex problems. The results of the case studies reinforced the perspective that discusses the role of the designer as a catalyst for organizational change in the domain of Design Thinking, and highlights the significant repetition of the benefit of the designer's mediation for the integration and absorption of the proposal of project by the team.

The association with business strategy is evidenced in the structure of the analyzed teams, which in almost all cases had UX designers responding directly to the business manager or to the commercial director, and deploying corporate's business goals into tactical metrics to justify the benefits of the processes of design for the final project 
results. However, the monitoring of technological developments did not seem to be associated with the activities of the designer, nor even with the use of Design Thinking. The influence of design on technological evolution was evidenced in a different way, with the potentialization of the variety of new ideas originated at the co-creation dynamics, giving rise to suggestions of new technologies.

Therefore, it is possible to identify as the second proposition that the domain of Design Thinking allows the designer to act as a catalyst for organizational changes by promoting the integration of the project team and the creation of new ideas based on market trends and on the user's vision, generating value in use aligned with the business strategy narrative, in line with the studies of Simon (1969), Rittel \& Webber (1973), Boland (2004), Brown (2008), Verganti (2008), Junginger (2008), Martin (2010), Dorst (2011), Mozota (2011), Hartson \& Pyla (2012) and Zurlo \& Cautela (2014).

The complex problems for which design tools have been tailored over the last decades are evident in the routine of the analyzed companies, specially in tackling the difficulties of understanding new contexts of use and consumption that are the reason for the greater investments in research of companies $A$ and $B$, which are larger and support more conservative business models and structures.

Company selection criteria did not required the adoption of a specific management model for the studied companies, however all analyzed companies reported the use of agile approaches for project management, with some cases in which the design manager was also project manager or product owner. The agile structure of the project team is useful to increase the synergy between the members and emphasizes the performance of UX Designer as a conciliator of requirements and solution facilitator, guaranteeing considerable relevance to this professional in the largest companies analyzed when they seek to align the different perspectives of the internal business units and the external user's view. The possibility of generating opportunities is real because, given the space to rethink the problem, the team opens up to a wider range of solutions, as well as suggestions for improvements brought by the service areas and other areas that have direct contact with the customer or who manage the brand. Although the related theory emphasizes the potential for innovation considering the combination of design and agile project management, no empirical evidence was obtained to support this hypothesis. Therefore, we emphasize the contribution of design for the agile team considering the strategic direction of the operational production, a fact observed in all companies, especially at the companies that claimed to have concluded a digital transformation process.

Therefore, the third proposition obtained from this research considers that agile project management is the most suitable option to generate value through design, since it deals the opportunities that emerge from the exploration of complex and unique problems and the use of the potential of design for the generation and harmonization of viable solutions contributing for the achievement of corporate strategy, in alignment with the concepts proposed by Chamberlain et al. (2006), Martin (2010), Amaral et al. (2011) and Sheffield \& Lemétayer (2013).

The previously presented propositions reinforce the strengths of the links between design and business promoted by the user experience area. Although the theory emphasizes the role of design management as the promoter of design, in the analyzed cases it was identified that it is not necessary an exclusive desisgn manager for design to propagate, although the creation of a management leadership for design at the managerial level brings maturity benefits of positioning and even the guarantee of 
obtaining resources for the execution of tests and more elaborated research, as one of the cases of greater maturity was able to evidence.

Obtained results also have evidenced that design activities are aligned with research and testing activities that are becoming more important, a fact verified in all the surveyed companies. However, the strict focus on the user's vision does not allow space for the development of more experimental solutions, capable of expanding the scope of a service and consequently its market. On the other hand, evidence from interviews and available data indicates that the design approach works to strengthen the organization's competitive differentials but does not necessarily establish new competitive advantages. According to the designers themselves, it is more interesting to deal with opportunities arising from an established competitive differential than creating opportunities to establish a new differential.

Therefore, this research considers as a fourth proposition that research and testing practices are the activities through which design disseminates at organizations, bringing the principles of business strategy closer to the delivery of value to the user, leading to organizational changes that create or reinforce competitive differentials in line with the concepts proposed by Gregory (1995), Dickson et al. (1995), Christensen (1997), Kotler (2002), Porter (2008a) and Mozota (2011).

\subsection{Interpretation framework}

The consolidation of the different propositions obtained along the topics of analysis originated an interpretation framework, able to illustrate the different ways in which design is incorporated as an agent of transformation at the companies, the central objective of this research.

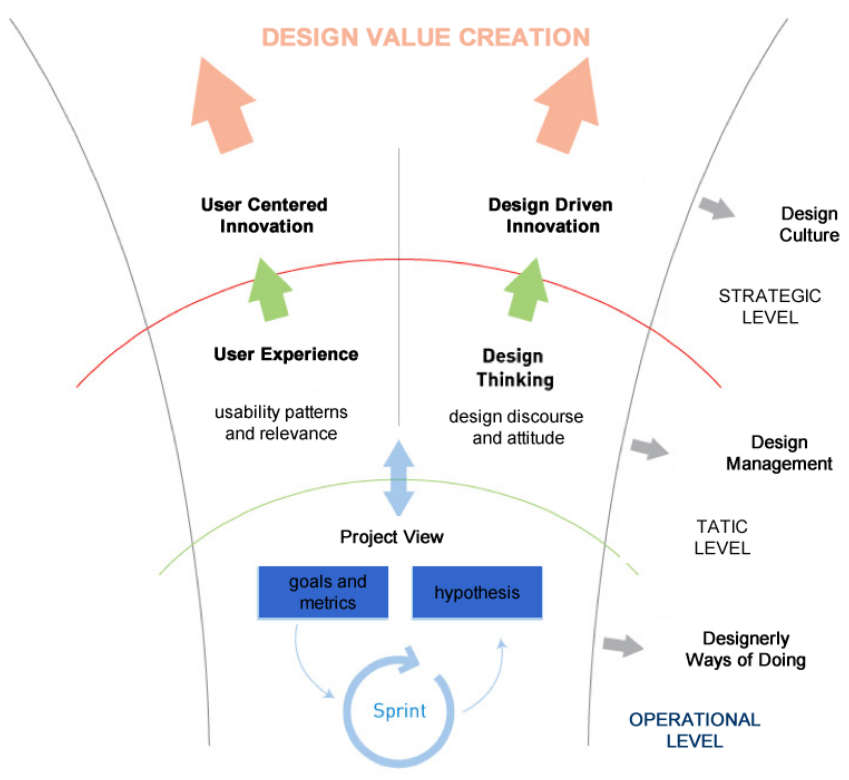

Figure 4. Interpretation framework for design management considering user experience. Source: Created by the authors. 
The proposed framework, presented in Figure 4, reveals a systemic view about the relationship between the obtained propositions and suggests that the development of design management amplifies the delivery of value to the user, while the user experience and design thinking serve as connectors between design, strategy and operations, creating relevant solutions, rethinking problems and evaluating opportunities that emerge from the design space in order to deploy performance indicators that reflect the satisfaction and the meaning of the service for the customer throughout the improvement cycles, guaranteeing a greater potential of delivering value to the customer considering the strategic narrative of the company.

The two-way arrow linking the operational and the tactical levels demonstrates that the results obtained with the improvements cycles can reinforce the new propositions that are evaluated in the context of design management considering the organization's strategic perspective.

\section{Conclusions}

This research aimed to investigate design practices in the operational, tactical and strategic dimensions of digital service companies to identify organizational changes caused by the adoption of a design management model, and the impact on the adoption of performance measures, aiming at the evolution of the theoretical construction that supports the practices of the area.

Performed analysis evidenced the adoption of professional practices in harmony with the theoretical backgrounds, increasing the validity of the suggested interpreation framework. This study also reports a reality when a significant number of companies are still creating their own design culture, supported by market research and user benchmarks, but already indicates how this process, whether it is user focused, market analysis, or in the intersection between these two areas, can be decisive for the success of solutions directed to the consumers or the treatment of problems of the own company.

The cases also evidenced the consolidation of UX's professionals as mediators and promoters of the design attitude among corporate areas, generating benefits for the development of products, quality of processes, and creating a holistic vision of the services needed to create relevant experiences for customers, involving all points of contacts for the service improvement, not focusing exclusively on the interface, as shown by the involvement of the customer service sectors in the determination of product scope.

It is possible to conclude that design practices have a great potential for promoting interdisciplinary integration, and UX area and business area are increasingly synergistic, narrowing the gap between business objectives and user's expectations with the use of design thinking as a common language, making discussions more efficient and productive, and adding improvements in the results of an agile project team, with the generation of a decisive input for the strategic decisions related to the business.

Regarding departmental design management, the generalization of the case studies did not find consistent standards to determine possible impacts on the strategy and performance indicators, requiring a more specific case study with companies that already have a more mature design management. Among the limitations of this research it is importante to observe that the use of a qualitative approach, despite of being able to generate substantiated propositions that have potential to sustain future 
explorations about the design process in organizations, as presented in the fourth section of this article, make it impossible to generalize in contexts besides the reality of the companies analyzed in this study. As a future study, we suggest the use of the four propositions identified and the interpretation reference as the basis for the establishment of a new questionnaire, to be verified quantitatively in organizations that have the design as an internal activity focused on the generation of differentials, at the levels operational, tactical and strategic.

\section{References}

Amaral, D. C., Conforto, E. C., Benassi, J. L. G., \& Araujo, C. (2011). Gerenciamento Ágil de Projetos: aplicação em produtos inovadores (2a ed.). São Paulo: Editora Saraiva.

Bargas-Avila, J. A., \& Hornbæk, K. (2011). Old wine in new bottles or novel challenges? A critical analysis of empirical studies of user experience. In $\mathrm{CHI}$ '11 Proceedings of the SIGCHI Conference on Human Factors in Computing Systems (pp. 2689-2698). Vancouver.

Boland, M. (2004). Managing as designing. Stanford: Stanford Business Books.

Brown, T. (2008). Design thinking. Harvard Business Review, 86(6), 84-92. PMid:18605031.

Brown, T., \& Katz, B. (2011). Change by design. Journal of Product Innovation Management, 28(1), 381-383.

Buchanan, R. (1992). Wicked problems in design thinking. Design Issues, 8(2), 5-21.

Buchanan, R. (2008). Design and organizational change. Design Issues, 1(24), 2-9.

Chamberlain, S., Sharp, H., \& Maiden, N. (2006). Towards a framework for integrating agile development and user-centred design. Lecture Notes in Computer Science, 4044, 143-153. http://dx.doi.org/10.1007/11774129_15.

Christensen, C. (1997). The innovator's dilemma: when new technologies cause great firms to fail. Boston: Harvard Business School Press.

Cross, N. (2001). Designerly ways of knowing: Design discipline versus design science. Design Issues, 17(3), 49-55.

Deserti, A., \& Rizzo, F. (2014). Design and the cultures of enterprises. Design Issues, 30(1), 3656.

Dickson, P., Schneier, W., Lawrence, P. \& Hytry, R. (1995). Managing design in small highgrowth companies. Journal of Product Innovation Management, 12(5), 406-414.

Dorst, K. (2011). The core of 'design thinking' and its application. Design Studies, 32(6), 521 532.

Eisenhardt, K. M. (1989). Building theories from case study research. The Academy of Management Review, 14(4), 532-550.

Fleury, A. L., Stabile, H. \& Carvalho, M. M. (2016). An overview of the literature on design thinking: Trends and contributions. International Journal of Engineering Education, 32(4), 1704-1718.

Galbraith, J. (2002). Organizing to deliver solutions. Organizational Dynamics, 31(2), 194-207.

Gentile, C., Spiller, N., \& Noci, G. (2007). How to sustain the customer experience? European Management Journal, 25(5), 395-410.

Gorb, P. (1995). Managing design in an uncertain world. European Management Journal, 13(1), 120-127. http://dx.doi.org/10.1016/0263-2373(94)00064-E.

Gregory, M. J. (1995). Technology Management: a process approach. Proceedings of the Institution of Mechanical Engineers, 209(5), 347-356.

http://dx.doi.org/10.1243/PIME_PROC_1995_209_094_02. 
Hartson, R., \& Pyla, P. (2012). The UX Book: Process and guidelines for ensuring a Quality User Experience (1a ed.). San Diego: Morgan Kauffman Publisher.

Hassenzahl, M. Experience design: Technology for all the right reasons. Williston, VT: Morgan \& Claypool Publishers, 2010.

Hassenzahl, M., Eckoldt, K., Diefenbach, S., Laschke, M., Len, E. \& Kim, J. (2013). Designing moments of meaning and pleasure: Experience design and happiness. International Journal of Design, 7(3), 21-31.

Junginger, S. (2008). Product development as a vehicle for organizational change. Design Issues, 24(1), 26-35.

Katz, B. (2015). Make it New: The history of silicon valley design. Massachussets: MIT Press. http://dx.doi.org/10.7551/mitpress/9780262029636.001.0001.

Kotler, P. (2002). Marketing management: millenium edition (10th ed.). Nova Jersey: Pearson Custom Publishing.

Krippendorf, K. (2006). The semantic turn: a new foundation for design. Boca Raton: Taylor \& Francis Group.

Kujala, S., Roto, V., Väänänen-Vainio-Mattila, K., Karapanos, E., \& Sinnelä, A. (2011). UX Curve: A method for evaluating long-term user experience. Interacting with Computers, 23, 473-483.

Lai, J., \& Yang, M. (2009). Introducing user centered design to mid-career professionals: experiences to build upon. In: Proceedings of the I International Association of Societies of Design Research (pp. 577-586.). Cincinati: IASDR.

Lallemand, C., Gronier, G., \& Koenig, V. (2015). User experience: A concept without consensus? Exploring practitioners' perspectives through an international survey. Computers in Human Behavior, 42(1), 35-48.

Law, E. L., Schaik, P., \& Roto, V. (2014). Attitudes towards user experience (UX) measurement. International Journal of Human-Computer Studies, 72, 526-541.

Mafakheri, F., Nasiri, F., \& Mousavi, M. (2008). Project agility assessment: An integrated decision analysis approach. Production Planning \& Control, 19(6), 567-576.

Martikainen, A., Niemi, P., \& Pekkanen, P. (2013). Developing a service offering for a logistical service provider - Case of local food supply chain. International Journal of Production Economics

Martin, R. (2010). Design de negócios (1a ed.). Rio de Janeiro: Editora Campus.

Mccutcheon, D. M., \& Meredith, J. R. (1993). Conducting case study research in operations management. Journal of Operations Management, 11(3), 239-256. http://dx.doi.org/10.1016/0272-6963(93)90002-7.

Moreira, D., \& Queiroz, A. C. S. (2007). Inovação organizacional e tecnológica. São Paulo: Thomson Learning.

Mozota, B. B. (2011). Gestão do Design: usando o design para construir valor de marca e inovação corporativa. Porto Alegre: Bookman,.

Norman, D. (2004). Emotional Design: Why we love (or hate) everyday things. Nova lorque: Basic Books. http://dx.doi.org/10.1145/985600.966013.

Norman, D. (2013). The design of everyday things. Basic Books.

Porter, M. E. (2008a). Estrategia competitiva: Técnicas para el Análisis de los setores industriales y de la competencia (38a ed.). Cidade do México: Grupo editorial Patria.

Porter, M. E. (2008b). The five competitive forces that shape strategy. Harvard Business Review, 6(1), 24-41. PMid:18271320.

Prahalad, C. K., \& Hamel, G. (1990). The core competence of the corporation. Harvard Business Review, 3(1), p. 79-90. 
Pucillo, F., \& Cascini, G. (2014). A framework for user experience, needs and affordances. Design Studies, 35(2), 160-179.

Rittel, H. W. J., \& Webber, M. M. (1973). Dilemmas in a general theory of planning. Policy Sciences, 4, 155-169.

Schön, D. A. (1988). Designing: Rules, types and words. Design Studies, 9(3),181-190.

Sheffield, J., \& Lemétayer, J. (2013). Factors associated with the software development agility of successful projects. International Journal of Project Management, 31(3), 459-472.

Simon, H. (1969). The sciences of the artificial. Cambridge, MA: MIT Press.

Simon, H. (1973). The structure of ill defined problems. Artificial Intelligence, 4(3-4), 181-201. http://dx.doi.org/10.1016/0004-3702(73)90011-8.

Thüring, M., \& Mahlke, S. (2007). Usability, aesthetics and emotions in human-technology interaction. International Journal of Psychology, 42(4), 253-264.

Varnali, K., \& Toker, A. (2010). Mobile marketing research: the-state-of-art. International Journal of Information Management, 30(2), 144-151.

Verganti, R. (2008). Design, meanings, and radical innovation: A metamodel and a research agenda. Journal of Product Innovation Management, 25(5), 436-456.

World Design Organization - WDO (2017). Definition of industrial design. Recuperado em 17 de novembro de 2017, de http://http://wdo.org/about/definition/

Yin, R. K. (2015). Estudo de caso: planejamento e métodos (5a ed.). Porto Alegre: The Bookman.

Zurlo, F., \& Cautela, C. (2014). Design strategies in different narrative frames. Design Issues, 30(1), 19-35. 